\title{
The Development of Multiple Intelligence Empowerent- Oriented Learning Media at Elementary Schools
}

\author{
I Komang Sudarma ${ }^{1}$, Ign. I Wayan Suwatra ${ }^{2}$, Dewa Gede Agus Putra Prabawa ${ }^{3}$ \\ \{ik-sudarma@undiksha.ac.id ${ }^{1}$, ignatiusiwayan.suwatra@undiksha.ac.id ${ }^{2}$, \\ dgap-prabawa@undiksha.ac.id\} \\ Department of Educational Technology, Universitas Pendidikan Ganesha, Indonesia ${ }^{123}$
}

\begin{abstract}
This research and development study is aimed at examining the quality of multiple intelligence-oriented learning media. This was effectively and efficiently carried out by adapting Hannafin and Peck model, which consists of: need analysis, design, development and implementation. Data were collected using questionnaires and the data obtained were analyzed using descriptive quantitatively method. Questionnaires were also given to two media and learning design experts. Three types of learning media were adopted in this study. The first were puppets, used to develop students' linguistics and spatial intelligences, the second was a comic, which was utilized to prosper students' kinesthetics and language intelligences, while the third was a counting box, used to develop students' logical/mathematics, spatial and language intelligences. The expert judgement showed that the score for the quality of the puppets, comic and counting box were 99,09, 96, and 97,99 respectively, with an average score of 97,00 all in the "very good" category.
\end{abstract}

Keywords: Learning media, multiple intelligences

\section{Introduction}

Gardner [1], divided intelligence into linguistics, mathematics/logical,spatial, kinesthetics, musical, interpersonal, intrapersonal, naturalist, and extential intelligence. These nine various types of intelligences are tagged "multiple intelligence," which are highly needed in the $21^{\text {st }}$ century. He went further to categorize them into intrapersonal and interpersonal intelligences..

Intrapersonal intelligence is one's ability to be responsible, hardworking, punctual, have the right work ethic. Those characteristics are the manifestations of the soft skills presently needed in the working environment. Interpersonal intelligence is also essential in communicating, diplomacy and in building cooperative and friendly environment in a cooperate association.[2] stated that the theory of multiple intelligences is the most precise model to use to evaluate the potentials in students.

The results of the study by Ahvan and Pour [1] showed that multiple intelligences similar to logical-mathematics, visual-spatial, verbal-linguistics, and physical-kinesthetic. Interpersonal, and intrapersonal intelligences have positive significant connection with students' learning achievements. This means that every individual has more than one type of intelligence that can be used as a basis to design academic materials needed to enhance students' learning ability. Therefore, teachers are expected to prepare learning materialswhich 
supports the development of multiple intelligences (MI). In doing this, they have to consider students' potential, motivation, interest and attitude [3]).

Learning at school generally emphasizes the empowerment of academic intelligence (linguistics and logical-mathematics). Unfortunately, not many teachers develop, support and empower those intelligences in their students. A good number of teachers and parents strongly believe that if their children have the best academic performance, they will be successful in the future. However, analysis has it that many people with high academic knowledge have ordinary lives while those with average academic achievements become successful, and wealthy.

The results of a study [6] on elementary schools indicate that knowledge, comprehension, and skills, of teachers in developing and empowering multiple intelligences on students is still very low. They tend to focus more on learning material, leaving out multi intelligence empowerment, which is very crucial for students to discover their skills. In addition, it was discovered that the lesson plans did not emphasize on multiple intelligence empowerment rather they focused on the empowerment of an intelligence type, for instance logical mathematics and linguistics intelligences. The lesson plans did not indicate the use of varied learning media that supported the development of students' multiple intelligences. [6]

Based on the results of the study [6] an academic strategy is needed to enable teachers help students to discover their intelligences. One way to do this is by developing multiple intelligence-oriented learning media. Theacademic tool to be designed and implemented should be able to: 1) present the message in more concrete forms, 2) make students active through interactive sections, 3) develop one or two intelligences at once, , and 4) enable students to identify the knowledge they possess (Sadiman, et al, 2006). Through this development, teachers are expected to develop students' ability to comprehend easier and students are expected to be able to recognize their own intellectual ability. Using the results of the analysis as basis the objective of this study, the quality of the learning media was examined usingHanafin and Peck model.

\section{Method}

This study is a research and development study. Picture 3.1 below, displays thedevelopmental model .

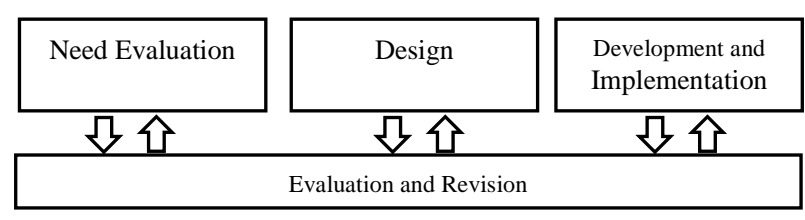

Fig 1. The Phases of Development of Hannafin\&Peck Model (1987) 


\section{Need Evaluation Phase}

Need evaluation is the first essential thing to do when producing a suitable learning product. This phase involves the analysis of thelearning process, material, and target (teachers and students) characteristics.

2. Design Phase

An important step that needs to be considered is the design phase. This phase focuses on three activities, namely: (a) selecting material (themes), (b) choosing the learning strategies that will be implemented, (c) designing itsframeworks.

3. Development and Implementation Phase

This phase translates the design into concrete physical forms. The prototype of the product is designed after which various steps are carried out to implement it.

4. Evaluation and Revision Phase

Based on the model of Hannafin\&Peck, evaluation and revision are done in every developmental phase. It is required to determine the priority scale of the problems discovered in the evaluation phase, and conduct revisions by experts and teachers during the design and implementation phases. However, in this study, evaluation is limited to the validation of experts.

The data were collected by distributing questionnaires. Questionnaires were used to obtain data from learning design and media experts. The data collected then were analyzed descriptively. The guideline used to determine the revision done is presented in Table 3.2 below.

Table 1. Conversion Guidelines Level of Achievement with Scale 5

\begin{tabular}{lll}
\hline \multicolumn{1}{c}{ Achievement Level (\%) } & \multicolumn{1}{c}{ Qualification } & \multicolumn{1}{c}{ Explanation } \\
\hline $90-100$ & Very good & No revision needed \\
$75-89$ & Good & Minor revision needed \\
$65-74$ & Adequate & Revise as needed \\
$55-64$ & Poor & Major revision needed \\
$0-54$ & Very poor & Product needs to be re-make \\
\hline
\end{tabular}

Sourse: Tegeh and Kirna (2010)

\section{Results}

The results of the analysis are presented based on Hannafin\&Peck model, which includes the phases of need analysis, design, development and implementation as well as evaluation.

\subsection{Need Analysis Phase}

The steps carried out in this phase were learning process and material analysis. The results of the analysis of former indicated that there were still limited number of multiple 
intelligence-oriented academic tools used in elementary schools. The existing media only facilitates a type of intelligence. As a result of this, a media capable of facilitating multiple intelligence need to be developed. Material analysis was conducted to determine the required materials that would be supported by multiple intelligence-oriented media and from the materials, the themes and the sub-themes refered to were determined. The results of the analysis indicated that learning media would be developed for two subjects; Bahasa Indonesia and Mathematics. From these two subjects, the material that would be supported by learning media were story telling and counting. Hence, the theme that would be refered to was "Environment".

\subsection{Design Phase}

The results of the material analysis led to the development to a media capable of accommodating multiple intelligences ( puppets, a counting box, and a comic). Puppets were designed to develop language, spatial, kinesthetics, interpersonal and intrapersonal intelligences. The counting box was developed to deveop logical/mathematics, language, spatial, and kinethetics intelligences, while the comic was designed to develop language, spatial, and intrapersonal intelligences.

\subsection{Development Phase}

This phase developed the design into a multiple intellegent-oriented academic tool. Based on the results of the analysis, 3 media were developed, namely puppets, a counting box, and a comic, as presented in Picture 4.1 below.

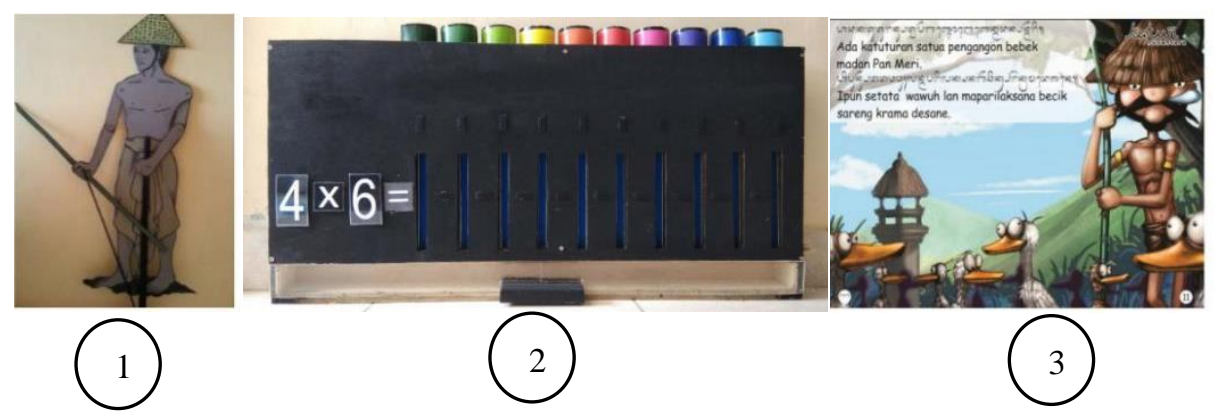

Fig 2. No. 1 The Puppet, No.2 The counting box, No. 3 The comic

\section{Evaluation and Revision Phase}

The learning media were evaluated to examine the validity. Questionnaires were used to evaluate this phase. Complete data on research results are available at https://osf.io/te6zx/. The evaluation results can be seen in Table 4.2 below.

Tabel 2. Evaluation Results by Experts

\begin{tabular}{cccccc}
\hline No & $\begin{array}{c}\text { The Name of the } \\
\text { Media }\end{array}$ & $\begin{array}{c}\text { Learning Design } \\
\text { Aspect }\end{array}$ & Category & $\begin{array}{c}\text { Media } \\
\text { Aspect }\end{array}$ & Category \\
1 & Puppets & 97,64 & Very Good & 99,09 & Very Good \\
\hline
\end{tabular}




\begin{tabular}{llllll}
\hline 2 & Comic & 96,25 & Very Good & 98,89 & Very Good \\
3 & Counting Box & 98 & Very Good & 96 & Very Good \\
\hline
\end{tabular}

\section{Discussion}

Mutiple intelligence-oriented learning media are effective in presenting concepts in the areas of mathematics, language, and in improving students' ability in mathematics, language, spatial, kinethetics, interpersonal and intrapersonal areas. This means that the tool can be used to develop students' spatial, kinesthetic, as well as intrapersonal and interpersonal intelligences. A couple of factors, made the media categorize it as "very good" which is based on its evaluation using media experts.

Learning design expert gave scores that were tagged "very good" because the tools developed were able to facilitate the production of multiple intelligences, easy to use, with self-explanatory instructions on how to use them. From the evaluation of the media expert, the scores given were categorized as "very good" because the media developed was unique, used interesting characters, could be touched, and were suitable for lower grades students of elementary schools. This is in line with the statement made by Smaldino et al (2011) that good visual media had to be able to make abtract messages concrete, motivative and direct students' attention.

\section{Conclusion}

Multiple intelligence-oriented learning media has successfully been developed in the forms of three media products. The first ones were puppets, which were designed to develop languaage, kinethetic, interpersonal and intrapersonal intelligences. The second was a counting box, which was designed to develop mathematics, language, spatial, kinethetics intelligences. And the third, acomic, designed to develop language, and intrapersonal intelligences. Experts judgements showed that the puppet media obtained score 99,09, the comic media 98, 89 and the counting box media 97,99, all of which were categorized as very good.

\section{References}

[1] Ahvan, YaghoobRaissi \& Pour.: Hossein Zainali. The correlation of multiple intelligences for the achievements of secondary students. Educational Research and Reviews, 11(4), 141-145. http://files.eric.ed.gov (2016)

[2] Amstrong, T.: Multiple intelligences in the classroom. Alexandria, Virginia: ASCD (1994)

[3] Gardner, H.: Multiple intlegences. The theory in practice. New York: Basic Book (1999)

[4] Handayani, Sri, Anita Trisiana, \&Sumardiono.: Development of English Language Learning Model with Multiple Intelligence Approach to Improve Students Character. International Journal of Education and Research, 3 (6), 401-410. http://www.ijern.com/journal (2015)

[5] Qureshi, Elena..: Instructional Design Models. Available at http://web2.uwindsor.ca/courses/edfac/morton/instructional_design.htm. (2015).

[6] Sadiman, A. S., Raharjo, R., Haryono, A., \& Rahardjito.; Media pendidikan, pengertian, pengembangan, dan pemanfaatannya. Jakarta: PT Raja Grafindo Persada. (2006) 
[7] Smaldino, S. E., Lowther, D. L., \& Russell, J. D.: Instructional technology \& media for learning: Teknologi pembelajaran dan media untuk belajar. (Terjemahkan Arif Rahman). Jakarta: Kencana. (2011)

[8] Sudarma, I K \&Adnyana, I Putu Budi.: Pengembangan BUTIK(buklet tematik integratif kontekstual) untuk memberdayakan kecerdasan multitalentasiswa sekolah dasar(SD). Laporan penelitian. Undiksha. (2015)

[9] Sudarma, I Komang, Tegeh, I Made , and Suwatra, I Wayan.: Pelatihan Dan Pendampingan Pembelajaran Berorientasi Multiple Intelligences Bagi Guru-Guru TK Di Kecamatan Buleleng. Senadimnas Proceding (2017)

[10] Tegeh, I M. \&Kirna, I M.: Metode penelitian pengembangan pendidikan. Teaching Materials. Singaraja: Undiksha (2010) 